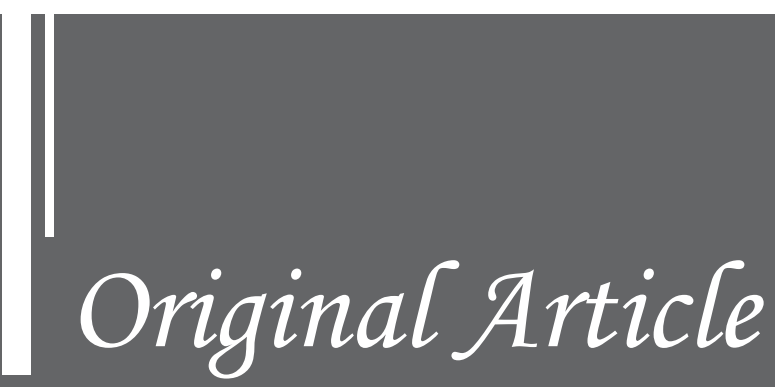

\title{
PHARMACOECONOMIC CONSIDERATIONS AND QUALITY OF LIFE ASSESSMENT IN HEPATITIS C PATIENTS
}

\author{
Khadija Sarwar ${ }^{1}$ Rabia Aslam ${ }^{1}$, Irfan Bashir ${ }^{1}$, Talha Jamshaid ${ }^{2}$, \\ Husnain Hamid ${ }^{1}$, Tooba Mehboob ${ }^{1}$, Naila Tabassam ${ }^{1}$, Muhammad \\ Jamshaid ${ }^{1}$
}

${ }^{1}$ Faculty of Pharmacy University of Central Punjab Lahore, Pakistan

${ }^{2}$ Faculty of Pharmacy and Alternative Medicine, The Islamia University Bahwalpur, Pakistan

Corresponding Author: Rabia Aslam, Email: rabiaaslam96@gmail.com

\begin{abstract}
Background: Gradual liver damage occurs due to hepatitis $\mathrm{C}$ virus $(\mathrm{HCV})$ that may result in liver fibrosis and even cancer. Pakistan is a developing country with the second highest prevalence $4.5-8 \%$ of hepatitis $\mathrm{C}$. The main purpose of this study was to estimate the quality of life of people affected with hepatitis, to create general awareness about the disease and to determine pharmacoeconomic considerations of hepatitis $\mathrm{C}$ treatment.

Methods: It was a cross-sectional study conducted in village Wali Pur Bura of District Nankana sahib, Punjab, Pakistan. Sample size determined by Daniels equation was 100, both male and female participants were included this study. The data was collected to assess the health status data of study population through validated questionnaire and a urdu version of tool EuroQol 5D-5L, comprising of five (5) questions covering the various aspects of health. Data were analyzed through SPSS version 16. Paired sample statistics for comparing two attributes of the study and frequencies were calculated.

Results: In current study, majority ( $70 \%$ ) of patients were belong to the lower class and only $39 \%$ patients were aware of Punjab Government's participation in hepatitis free treatment plan. $60 \%$ patients showed marked reduction in quality of life and the reason behind was painful interferon therapy. Poor quality of life is observed due to the extra hepatic symptoms of HCV including depression. According to the health scale of 60 participants out of 100 was having below Average health status, 21 participants possessed Average Health while 19 participants had Excellent Health.

Conclusion: Hence, concluded that due to hepatitis $\mathrm{C}$, health as well as socioeconomic and family life is badly affected. Majority of the participants were having poor quality of life. Costly treatment is beyond the reach of majority of rural population that increases the incidence of depression among patients and their families.
\end{abstract}

Keywords: Hepatitis C, quality of life, socioeconomic, rural areas. 


\section{Introduction}

Gradual liver damage occurs due to hepatitis $\mathrm{C}$, which results in cancer of liver cells and liver fibrosis. Globally more than 185 million people have been infected with $\mathrm{HCV}$, out of them 3,50,000 die every year (1). Globally, Pakistan is at the second number who has high prevalence of hepatitis $\mathrm{C}(4.5 \%$ to 8.0$)$ (2). $\mathrm{HCV}$ is a hepatotropic RNA virus and belongs to the flaviviridae family (3). HCV infected person is the main carrier for the transfer of hepatitis C. In present, most widely spread blood borne disease is hepatitis $\mathrm{C}$. It is calculated that the cases of $\mathrm{HCV}$ will increases in the future and it will be a main cause of hepatocellular carcinoma (4). HCV patients have multiple signs and symptoms of disease, which ranges from the lack of clinical manifestation to the presence of entire body symptoms, which includes loss of appetite and tiredness. At advance stage, abnormal accumulation of fluid in the abdominal cavity occurs other complications include hepatic encephalopathy and jaundice (5). It is not only a hepatic disorder but also a psychosocial disease (6). $20 \%-40 \%$ patients with chronic hepatitis $\mathrm{C}$ develop liver fibrosis or hepatocellular carcinoma that leads towards liver failure and ultimately death. The chances of liver cancer in patients with $\mathrm{CHC}$ reaches $1 \%-4 \%$ each year (7). Test for hepatitis $\mathrm{C}$ diagnosis divided into two categories: serological assays that determine anti-HCV antibodies and molecular assays that discover, represent or quantify HCV RNA genomes. For screening of anti-HCV serological assays are used like, the Recombinant Immunoblot Assay (RIBA) and the enzyme immunoassay (EIA) (8).

\section{Quality of life of Hepatitis C patients}

According to different studies, all patients affected with Hepatitis C, don't have compromised quality of life and other chronic symptoms associated with the disease. (9). While on contrast some other studies indicated have a reduced HRQOL in HCV patients (10). Even patients who did not show any signs of cirrhosis, confronted different psychological and physical problems (10). Extra hepatic symptoms of $\mathrm{HCV}$ infection including anxiety, myalgia, gastrointestinal disturbances, depression and fatigue may exacerbate the quality of life (11).

Gender difference is important factors in $\mathrm{HCV}$ infection as number of studies shows that women have more worsen quality of life than men. Reduced quality of life is due to the somatic side effects associated with interferon-ribavirin therapy. Relapse $\mathrm{HCV}$ is also associated with poor quality of life (12). The high cost of treatment also disturbs the patient psychologically (11).The poor quality of life is also due to non-viral factors, such as psychiatric disturbance associated with previous IV drug use(10). Patient's negative perception about his or her disease is also alter the quality of life. They believe that their disease is responsible for disconnecting them from social activities that leads them towards social loneliness. HCV can cross BBB and cause mood changes, depression is also one of the major factor which reduces the patient's quality of life (11).

Pharmacoeconomic considerations of Hepatitis $\mathrm{C}$

A large number of individuals having $\mathrm{HCV}$ infection are unaware about their disease (13). Benefit from the treatment can be identified by screening. Mass screening for $\mathrm{HCV}$ infection has significant economic concerns which are linked with different additional diagnostic tests such as liver biopsies and also with the cost of screening test using different assays (14)

HCV executes a high economic burden globally. In 2012, the healthcare cost of $\mathrm{HCV}$ infection was 6.5 billion dollars and it is estimated that the cost will be reach at 9.1 billion dollars by the year 2024 (15). In developed countries treatment of Hepatitis of C with boceprevir or telaprevir and pegylated interferon/ribavirin has been estimated as cost-effective (16). Treatment cost are estimated to be in the range of US\$24000-39000 lifetime disease costs, for liver transplant and for the treatment of decompensated cirrhosis, other than antiviral treatment $(17,18)$.

Currently the annual costs of acute $\mathrm{HCV}$ infection and $\mathrm{CHC}$ is nearly 600 million US dollar (19), and it will be expected to be 184 billion US dollar over the period 2010-2019 (20), sofosbuvir-based treatment cost for one patient in the US is 85000-110000 US dollars (13), it is indicating the high burden of chronic $\mathrm{HCV}$ infection for national health systems, even country having low prevalence of $\mathrm{HCV}$ infection. In the ten European union countries the cost of HCV therapy is approximately $€ 50$ ?million. HCV causing considerable costs to world. The estimate Cost for Spain for HCV infection will be nearly $€ 3$ ?billion over the period of 2010-2030 (21). In Canada the costs are estimated to be 150 million canadian dollars annually until 2040 (22).

Methodology

A cross sectional study based on questionnaire was conducted in village Wali Pur Bura, Nankana sahib, Punjab, Pakistan.

\section{Sample Size}

Sample size determined through Daniels equation for our study was 100 .

\section{Informed consent}

As study was conducted in a village (Nankana Sahab, Punjab Pakistan) where most people were illiterate due to that reason informed consent was taken orally.

Inclusion Criteria

Both males and females having HCV infection, individuals who have had been received treatment against Hepatitis- $\mathrm{C}$, and age above 18 years.

\section{Exclusion Criteria}

Pregnant women, individuals having others infectious diseases including Hepatitis A, AIDS and hepatitis B, children are excluded, individuals who are under 18 and alcoholic.

\section{Data Collection Tools}

Validated EuroQol 5D-5L urdu version questionnaire tool comprising of five (5) questions covering the various aspects of health was used to assess the health status data of study population. Health status data was further graded up using health scale developed by EuroQol Foundation with due permission.

Data Analysis Tools

Data were analyzed through SPSS version 16 by applying paired sample statistics for comparing two attributes of the study and frequencies were calculated. Patient's quality of life was analyzed through predesigned EU-QOL 5D which includes questions comprising different factors like self-care, mobility, usual activities, depression, pain/discomfort.

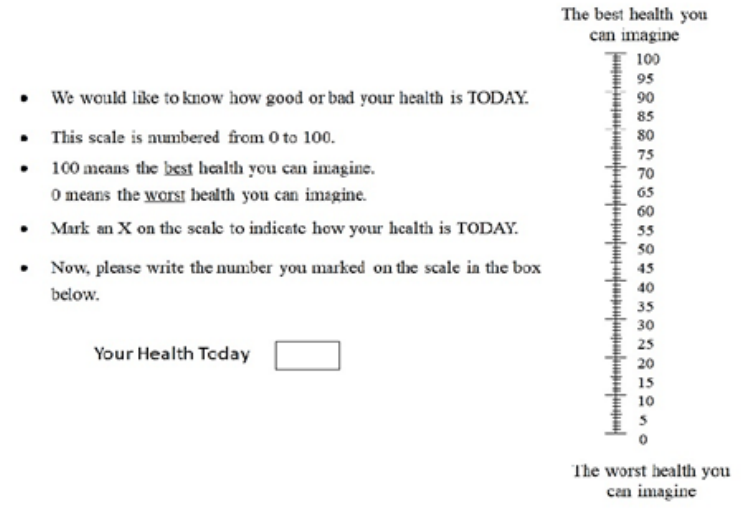

\section{Figure 1: Health Score Scale}

Ethics of Study

Data was collected after the permission of particular individual either male or female to maintain the ethics of this study. Research procedure was completed under ethical considerations as per Helsenki Declaration, ICH and GCP guidelines. Informed consents were taken from the participants. Confidentiality of their identity and information was made sure. Risk/benefit ratio was measured and the benefits of the study were higher than the risks. Formal permission to carry out the research project in the form of official letter bearing reference number FYR/ ERC/11/2018 was taken from Ethical Committee of Foundation for Young Researchers, Lahore, Pakistan

Results and Discussion

Table 1: Study Parameters of HCV Patients Related to Pharmacoeconomic Considerations $n=100$

\begin{tabular}{|l|c|c|c|c|}
\hline \multirow{2}{*}{ Parameters } & \multicolumn{2}{|c|}{ yes } & \multicolumn{2}{c|}{ No } \\
\cline { 2 - 5 } & Frequencies & Percentage & Frequency & Percentage \\
\hline Treatment through loan & 58 & $58 \%$ & 42 & $42 \%$ \\
\hline $\begin{array}{l}\text { Knowledge about } \\
\text { Government Free } \\
\text { Treatment Plan }\end{array}$ & 39 & $39 \%$ & 61 & $61 \%$ \\
\hline $\begin{array}{l}\text { Compliance with } \\
\text { Prescribed Treatment }\end{array}$ & 53 & $53 \%$ & 47 & $47 \%$ \\
\hline Conventional Treatment & 37 & $37 \%$ & 63 & $63 \%$ \\
\hline
\end{tabular}


Table 2: Study parameters of $\mathrm{HCV}$ patient related to treatment strategies $n=100$

\begin{tabular}{|l|l|c|c|}
\hline Parameters & Category & $\begin{array}{c}\text { Frequency } \\
\text { (n) }\end{array}$ & $\begin{array}{c}\text { Percentages } \\
\text { (\%) }\end{array}$ \\
\hline Socio-economic Status & Lower Class & 70 & $70 \%$ \\
\cline { 2 - 4 } & Middle Class & 30 & $30 \%$ \\
\hline Monthly Incomce & less than 20, 000/ Rs. & 70 & $70 \%$ \\
& More than 20, 000/ Rs. & 29 & $29 \%$ \\
\hline Family member & Less than 3 & 61 & $61 \%$ \\
& More than 5 & 39 & $39 \%$ \\
\hline
\end{tabular}

Out of participants $70 \%$ patients were belong to the lower class and having monthly income less than 20,000 and 39\% families having more than 5 members and that causes burden on the expenses (Table 2). In developing countries treatment cost of hepatitis is much high (23) and life time health care cost of HCV infected person is much high as compare to healthy person (24). Due to these factors unaffordability of treatment is much common in Pakistan. Due to the poor economic conditions and high treatment cost of $\mathrm{HCV} 58 \%$ patients took loan to get the costly treatment of HCV.

Out of 100 only $39 \%$ patients know Punjab Government is providing free treatment (Table 1) but most of they said Government providing medicines only to those who have reference and mostly low quality medicines are dispensed and it is also a time consuming process. More than half of population is unaware of this program. 53\% patients were compliant with their treatment this rate is lower because of lack of knowledge. Virologic response of medicine can only be achieved through medicine adherence in HCV patients High cost is the major attribute contributing in noncompliance. It can lead to reduce outcome of therapy and different side effects. Patient motivation is required to optimize therapy outcome (25). Approximately $37 \%$ patients were also taking conventional treatment along with allopathic. Out of these many patients were having firm believe that they were cured by conventional treatment.

Table 3: Frequency distribution in different attributes obtained through Euro-qol 5D Tool $n=100$

\begin{tabular}{|l|c|c|}
\hline Mobility & $\begin{array}{c}\text { Frequency } \\
\text { (n) }\end{array}$ & $\begin{array}{c}\text { Percentage } \\
\text { (\%) }\end{array}$ \\
\hline I have no problems in walking about & 04 & $04 \%$ \\
\hline I have slight problems in walking about & 25 & $25 \%$ \\
\hline I have moderate problems in walking about & 33 & $33 \%$ \\
\hline I have severe problems in walking about & 35 & $35 \%$ \\
\hline I am unable to walk & 03 & $03 \%$ \\
\hline Self-Care & 06 & \\
\hline I have no problems washing or dressing myself & 06 & $06 \%$ \\
\hline I have slight problems washing or dressing myself & 25 & $25 \%$ \\
\hline I have moderate problems washing or dressing myself & 43 & $43 \%$ \\
\hline I have severe problems washing or dressing myself & 23 & $23 \%$ \\
\hline I am unable to wash or dress myself & 03 & $03 \%$ \\
\hline Usual Activities & & \\
\hline I have no problems doing my usual activities & 03 & $03 \%$ \\
\hline I have slight problems doing my usual activities & 25 & $25 \%$ \\
\hline I have moderate problems doing my usual activities & 32 & $32 \%$ \\
\hline I have severe problems doing my usual activities & 34 & $34 \%$ \\
\hline I am unable to do my usual activities & 06 & $06 \%$ \\
\hline Pain/Discomfort & & \\
\hline I have no pain or discomfort & 0 & $0 \%$ \\
\hline I have slight pain or discomfort & 19 & $19 \%$ \\
\hline I have moderate pain or discomfort & 16 & $16 \%$ \\
\hline I have severe pain or discomfort & 18 & $47 \%$ \\
\hline I have extreme pain or discomfort & 47 & \\
\hline Anxiety/Depression & & $02 \%$ \\
\hline I am not anxious or depressed & 02 & $05 \%$ \\
\hline I am slightly anxious or depressed & 05 & $21 \%$ \\
\hline I am moderately anxious or depressed & 13 & \\
\hline I am severely anxious or depressed & 21 & $60 \%$ \\
\hline I am extremely anxious or depressed & 59 & $21 \%$ \\
\hline Health Scale Number & & \\
\hline Below 50 = Health Below Average & 60 & 21 \\
\hline 50 = Average Health & 19 & \\
\hline 100 = Excellent Health & & \\
\hline & & $19 \%$ \\
\hline & & \\
\hline
\end{tabular}

Quality of life of people, suffering from Hepatitis C, is badly affected by the. Muscular or joint pains, fatigue, depression and other psychological problems are most commonly associated with this chronic disease (26). Fatigue, either mental or physical, is the mos frequently documented complaint of $\mathrm{HCV}$ infected patients (27) About $35 \%$ patients had severe problem in walking due to poor health condition during $\mathrm{HCV}$ infection. $33 \%$ had moderate problem in walking. $43 \%$ patients had moderate problem in washing or dressing while $23 \%$ patients had severe problem while doing dressing. Due to $\mathrm{HCV}$ infection $34 \%$ patients had severe problems while performing their usual activities. Many patients had lost their job due to this disease and suffer from severe financial crisis. $47 \%$ patients had extreme pain in HCV infection. That was due to extra hepatic symptoms of HCV infection as well as painful interferon therapy. According to findings of present study HCV patients were found be suffering from depression. Out of 100 patients $59 \%$ were extremely depressed. It has been reported that HVC have capability to cross blood brain barrier thus leads to mood swings and depression (28) and anti-viral drugs also disturb the psychological health of the patients(27). Irritability and stress associated with HCV patients has a negative impact on their interpersonal relationships that results into to visible change in behavior of HCV patients. That shows significantly compromised or reduced quality of life of $\mathrm{HCV}$ patients. This poor quality of life is due to the extra hepatic symptoms of HCV including depression. The above mentioned symptoms e.g. impaired mobility, fatigue and depression disturb the person's working ability all together (29). The high cost of treatment also disturbs the patient's financial life which has impact on patient's quality of life.

Overall health status of the participants was evaluated by employing Health Scale Number as shown in Fig. 1. According to this scale it was found that health of 60 participants out of 100 was Below Average, 21 participants possessed Average Health while 19 participants had Excellent Health (Table 3).

\section{Conclusion}

There is a marked decline in the quality of life of patients suffering from hepatitis C. This decline is majorly due to the extra hepatic effects and common symptoms of this disease. Interferon therapy is another reason of compromised health status. Financial status of hepatitis $\mathrm{C}$ patients usually declines because the treatment of hepatitis $\mathrm{C}$ is not costeffective. Costly treatment is beyond the reach of majority of rural population that increases the incidence of depression among patients and their families.

\section{Recommendations}

Patient compliance can be improved by informing the patients regarding potential side effects of interferon, before starting the interferon therapy. Prevalence of hepatitis $\mathrm{C}$ can be decrease in rura areas by providing easy access of Punjab government free treatment plan of hepatitis $\mathrm{C}$ to common people.

\section{References}

1 .

Mohd Hanafiah K, Groeger J, Flaxman AD, Wiersma ST Global epidemiology of hepatitis $\mathrm{C}$ virus infection: New estimates of age? specific antibody to HCV seroprevalence. Hepatology. 2013;57(4):1333-42.

2. Jiwani N, Gul RB. A silent storm: hepatitis C in Pakistan Journal of Pioneering Medical Sciences. 2011;1(3):89.

3. Manns MP, Buti M, Gane E, Pawlotsky J-M, Razavi H, Terrault N, et al. Hepatitis $\mathrm{C}$ virus infection. Nature Reviews Disease Primers. 2017;3:17006.

4. Shalmani HM, Ranjbar M, Alizadeh AHM Recommendations for prevention and control of hepatitis $\mathrm{C}$ virus (HCV) infection and HCV-related chronic disease. $\mathrm{J}$ Liver. 2013;3(147):2167-0889.1000147.

5. Cho HJ, Park E. Quality of life of chronic hepatitis C patients and its associated factors. Osong public health and research perspectives. 2017;8(2):124.

6. Miller ER, McNally S, Wallace J, Schlichthorst M. The ongoing impacts of hepatitis c-a systematic narrative review of the literature. BMC Public Health. 2012;12(1):672

7. Marinho RT, Barreira DP. Hepatitis C, stigma and cure World Journal of Gastroenterology: WJG. 2013;19(40):6703.

8. Scott JD, Gretch DR. Molecular diagnostics of hepatitis C virus infection: a systematic review. Jama. 2007;297(7):724-32.

9. Alter HJ, Conry?Cantilena C, Melpolder J, Tan D, Van Raden M, Herion D, et al. Hepatitis C in asymptomatic blood donors. Hepatology. 1997;26(S3).

10. Foster G, Goldin R, Thomas H. Chronic hepatitis C virus infection causes a significant reduction in quality of life in the absence of cirrhosis. Hepatology. 1998;27(1):209-12.

11. Malhotra P, Malhotra N, Malhotra V, Chugh A, Singh I, Chaturvedi A, et al. Impact of Hepatitis C on Quality of Life. 
12. Strauss E, Porto-Ferreira FA, de Almeida-Neto C, Teixeira MCD. Altered quality of life in the early stages of chronic hepatitis $\mathrm{C}$ is due to the virus itself. Clinics and research in hepatology and gastroenterology. 2014;38(1):40-5.

13. Alter MJ, Margolis HS. Recommendations for prevention and control of hepatitis $\mathrm{C}$ virus (HCV) infection and $\mathrm{HCV}$ related chronic disease. 1998.

14. Alter MJ, Kuhnert WL, Finelli L, Control CfD, Prevention. Guidelines for laboratory testing and result reporting of antibody to hepatitis C virus. 2003.

15. Qureshi S, Qazi M, Aziz MT. Pharmacoeconomic analysis of treatment of patients infected with hepatitis $\mathrm{C}$ virus. Pakistan journal of pharmaceutical sciences. 2018;31(2).

16. Martin NK, Vickerman P, Miners A, Foster GR, Hutchinson SJ, Goldberg DJ, et al. Cost?effectiveness of hepatitis C virus antiviral treatment for injection drug user populations. Hepatology, 2012:55(1):49-57.

17. Wong JB, McQuillan GM, McHutchison JG, Poynard T. Estimating future hepatitis $\mathrm{C}$ morbidity, mortality, and costs in the United States. American Journal of Public Health. 2000;90(10):1562.

18. Siebert U, Sroczynski G, Rossol S, Wasem J, RavensSieberer U, Kurth B, et al. Cost effectiveness of peginterferon?-2b plus ribavirin versus interferon ?-2b plus ribavirin for initial treatment of chronic hepatitis C. Gut. 2003;52(3):425-32.

19. Moyer L, Mast E, Alter M. Hepatitis C: Part I. Routine serologic testing and diagnosis. American family physician. 1999;59(1):79-88, $91-2$.

20. Shah BB, Wong JB. The economics of hepatitis C virus. Clinics in liver disease. 2006;10(4):717-34

21. Buti M, San Miguel R, Brosa M, Cabasés JM, Medina M, Casado MA, et al. Estimating the impact of hepatitis $C$ virus therapy on future liver-related morbidity, mortality and costs related to chronic hepatitis C. Journal of hepatology. 2005;42(5):639-45.
22. El Saadany S, Coyle D, Giulivi A, Afzal M. Economic burden of hepatitis $\mathrm{C}$ in Canada and the potential impact of prevention. The European Journal of Health Economics. 2005;6(2):159-65.

23. Obach D, Deuffic-Burban S, Esmat G, Anwar WA, Dewedar S, Canva V, et al. Effectiveness and costeffectiveness of immediate vs. delayed treatment of $\mathrm{HCV}$ infected patients in a country with limited resources: the case of Egypt. Clin Infect Dis. 2014;58(8):1064-71.

24. Razavi H, ElKhoury AC, Elbasha E, Estes C, Pasini K, Poynard T, et al. Chronic hepatitis C virus (HCV) disease burden and cost in the United States. Hepatology. 2013;57(6):2164-70.

25. Wilkinson M, Crawford V, Tippet A, Jolly F, Turton J, Sims $\mathrm{E}$, et al. Community?based treatment for chronic hepatitis C in drug users: high rates of compliance with therapy despite ongoing drug use. Alimentary pharmacology \& therapeutics. 2009;29(1):29-37.

26. Hsu PC, Federico CA, Krajden M, Yoshida EM, Bremner $\mathrm{KE}$, Anderson FH, et al. Health utilities and psychometric quality of life in patients with early?and late?stage hepatitis $\mathrm{C}$ virus infection. Journal of gastroenterology and hepatology. 2012;27(1):149-57.

27. Karaivazoglou K, Iconomou G, Triantos C, Hyphantis T, Thomopoulos K, Lagadinou M, et al. Fatigue and depressive symptoms associated with chronic viral hepatitis patients. health-related quality of life (HRQOL). Ann Hepatol. 2010;9(4):419-27.

28. Wilson MP, Castillo EM, Batey AM, Sapyta J, Aronson S. Hepatitis C and depressive symptoms: psychological and social factors matter more than liver injury. The international journal of psychiatry in medicine. 2010;40(2):199-215.

29. Foster GR. Quality of life considerations for patients with chronic hepatitis C. Journal of viral hepatitis. 2009;16(9):605-11. 